\title{
Economics
}

2017; 6(4): 48-50

http://www.sciencepublishinggroup.com/j/eco

doi: 10.11648/j.eco.20170604.12

ISSN: 2376-659X (Print); ISSN: 2376-6603 (Online)

\section{Can Saemaul Undong Be Replicated in China}

\author{
Bin Wan ${ }^{1}$, Yaowu $\mathrm{Xu}^{2}$, Yang Bai ${ }^{3, *}$ \\ ${ }^{1}$ Ajou University, Suwon, Republic of Korea \\ ${ }^{2}$ Hunan International Economics University, Changsha, China \\ ${ }^{3}$ Ajou University, Suwon, Republic of Korea
}

\section{Email address:}

wanbinwanshen123@163.com (Bin Wan), qinyuanchunhy@163.com (Yaowu Xu),b198716y@hotmail.com (Yang Bai)

${ }^{*}$ Corresponding author

\section{To cite this article:}

Bin Wan, Yaowu Xu, Yang Bai. Can Saemaul Undong Be Replicated in China. Economics. Vol. 6, No. 4, 2017, pp. 48-50. doi: $10.11648 /$ j.eco.20170604.12

Received: May 22, 2017; Accepted: July 13, 2017; Published: November 3, 2017

\begin{abstract}
In the process of rural development, there are many cases of failure all over the world. Nevertheless, Korea Saemaul Undong is a great success admired by the entire world, which is proven to be a successful case in raising economic income and improving living conditions in rural areas. The purpose of the study is to examine the factors behind the success of Saemaul Undong and analyze what we can learn from Korea Saemaul Undong and whether it is a cure-all can be replicated in China or other developing countries today.
\end{abstract}

Keywords: Saemaul Undong, Guiding Spirits of Saemaul Undong, Successful Factors of Saemaul Undong

\section{Introduction}

Generally, several successful factors influence Korea's economic development: the Five-Year Economic Development Plan series, Korea Saemaul Undong and the 1988 Seoul Olympics, which were considered turning points in Korea's development. The successful Five-Year Economic Development Plan and Korea Saemaul Undong are the two wings of Korea's development. Saemaul Undong, which represents the development history of Korea, is a great Korean heritage admired by the entire world.

The authors conduct this research to study the case of Korea Saemaul Undong, trying to find the factors behind its success. Thus, in this work, the authors mainly study about the factors behind the success of Saemaul Undong and analyze what we can learn from Korea Saemaul Undong and whether it is a cure-all can be replicated in China or other developing countries today. How to emulate and disseminate the experience of Saemaul Undong? Is it possible to conduct the Saemaul Undong in urban and rural areas in China as well?

Saemaul Undong is a movement to achieve a better life through overcoming poverty. It aims to improve life not only for myself, but for my village and society as a whole. A better life means improvement in both mental and physical well-being. Saemaul Undong played an important role in developing Korea from a hopeless country to a modern industrial state, from aid recipient to donor, as you can see the following figure.

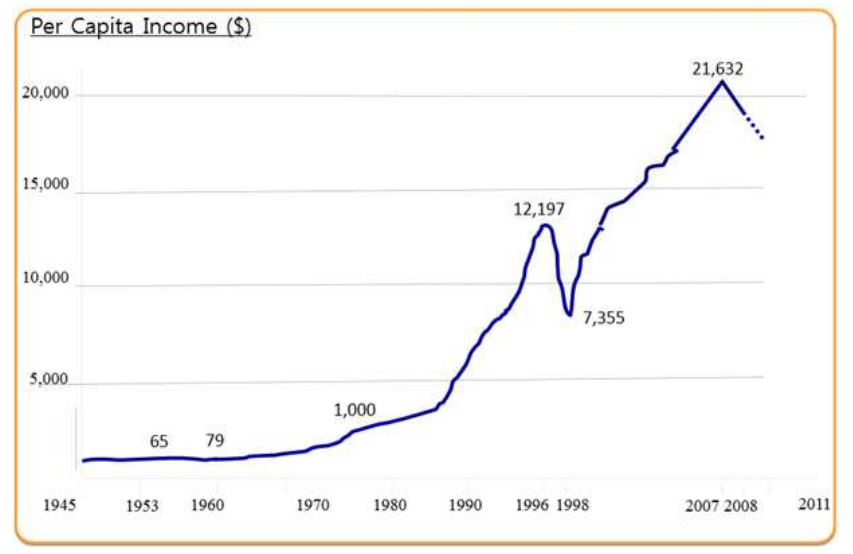

Figure 1. Chart of Per Capita Income (\$) in South Korea.

\section{Time Value of Money}

In order to understand the great success of Saemaul Undong better, it is essential to shed light on the concept of time value of money first.

As long as an opportunity exists to earn interest, the value 
of money is affected by the point in time when the money is received. A dollar received today can be worth more than a dollar received in the future. The sooner you receive money from an investment, the better. The sooner your money can begin earning interest, the faster it will grow.

The accumulation of wealth $W_{n}$ is computed as below.

Doing work for others: $W_{n}=\left\{\begin{array}{c}12 a n+C, r=0 \\ 12 a \cdot \frac{1-(1+r)^{n}}{1-(1+\mathrm{r})}+C, r \neq 0\end{array}\right.$ where $\mathrm{C}$ stands for principal (initial amount), $\mathrm{n}$ is discrete time period in terms of year, a is monthly salary (increases a little year by year), $r$ is the annual growth rate in monthly salary ( $r$ is constant). a and $\mathrm{r}$ are determined by knowledge, wisdom and luck;

Investment or starting an undertaking: $W_{n}=\mathrm{C} \cdot(1+\mathrm{r})^{n}$ where $\mathrm{C}$ stands for principal (initial amount), $\mathrm{n}$ is discrete time period in terms of year, $r$ is rate of return. $r$ is determined by wisdom and luck.

Therefore, the accumulation of wealth is related to time, principal, knowledge, wisdom and luck.

\section{Success Factors of Saemaul Undong}

\subsection{Prerequisite}

There are several preconditions behind the success of Korea Saemaul Undong. For one thing, communities with strong tradition of cooperation are consistent with the guiding spirits of Korea Saemaul Undong. For another, the reform of farmland makes farmers get rid of the dependence on the landlord. Even though the government and the capitalists but not farmers benefited most in the adjustment process of all previous land policy in South Korea, land reform eliminated the land ownership of landlord and established the land ownership of farmland [2]. Thirdly, in the 1960s, economy kept growth continuously. Moreover, compulsory military service for males strengthened men both physically and mentally. Finally, rapid decline in illiteracy rate among adults since 1945 was good for villagers to accept education and communicate. In 1968 , there was only $15 \%$ of illiteracy rate among adults, which would lead people towards universal literacy.

\subsection{The Correct Localization of Korea Saemaul Undong, Appropriate Methodology to Escape from Poverty}

Saemaul Undong was in the right direction, and it is of the local people, for the local people. It started from the agricultural sector and focused on the rural areas. And the methodology to escape from poverty was appropriate. Then Korean government conducted the specific projects towards the right direction by the local people, starting with a project small in scale, easy to accomplish.

\subsection{National Leadership and Strategies, Policies of the Government}

As many regional development theories point out, the substantial stumbling block to the development of a remote area is not the lack of investment but a lack of revolutionary leadership [4]. Each government is responsible for the growth of its society and the Korean government was at the forefront of implementing Saemaul Undong. Korean government helped those villages that helped themselves. Incentive system and competition obviously played an important role in Korea Saemaul Undong. The second year, the government applied principle of competition, support was given only to the villages that had the will to develop. And preferential support was given to outstanding villages, such as 500 sacks of cement and 1 ton of steel bars were supplied for 16600 outstanding villages additionally. In addition, at the early stage of Saemaul Undong, development of villages by level is one factor behind its success. Villages were classified into basic-level villages, self-help villages and self-reliant villages, depending on the level of development of villages. Villagers' initiative and spontaneous participation accelerated its development.

\subsection{Universal Value of Saemaul Undong's Guiding Spirits}

Saemaul Undong is guided by three central social values in Korean society, which are diligence, self-help and cooperation. History has illustrated a nation's fate hinges upon the mentality of its people, whether in east or west, present or past One who is diligent, cooperative and can help oneself can help construct a mature and moral society characterized by national harmony and social integration. [4]

\section{Saemaul Undong Cannot Be Replicated in China}

Korea Saemaul Undong has become a national brand for sharing its own development experience with other countries and many developing countries are studying Korea Saemaul Undong today. Meanwhile, lots of Chinese scholars, government officials and rural cadres start to learn Korea Saemaul Undong. They thought it was a shortcut to replicate Korea Saemaul Undong, due to the common oriental cultural background and similarity in economic model dominated by government between China and South Korea. But it turns out there are great difference between these two countries. There are as follows,

Firstly, social systems of the two countries are different. South Korea is a capitalist country and the economic system is private ownership economy. However, China's market economy is based on public ownership. Secondly, there exist different economic foundations in the two countries. The rural economic foundation in China is better than Korea, which is similar to the condition of basic completion of Saemaul Undong in Korea. Finally, there are diverse goals of new countryside construction among these two countries. The goal of Korea Saemaul Undong is relatively single, the economic factor comes first. In Korea, the gap between urban and rural areas is not too huge. Hence, it is relatively easier to achieve the goal of relieving urban pressure via speeding up the rural construction. However, in China the gap between urban and rural areas is much greater than in Korea, thus, basic goal of 
new rural construction in China is to meet the basic needs of rural society in order to achieve social stability, and then it is time to solve the problem of gap between urban and rural areas. Furthermore, it is unusually difficult to set up a unified goal for all provinces and autonomous regions. In a word, there are different national conditions and development stages between China and South Korea, so it is not rational to replicate Saemaul Undong in China.

In closing, in human history, there is no theory has ever been able to explain all the problems. Korea's rural development experience should be shared, leaders from developing countries can draw general lessons and leaders must adapt the Saemaul Undong approach to their own countries. [1] Saemaul Undong is not a cure-all for all the rural problems, and it cannot cure all.

\section{Conclusions and Recommendations}

Korea Saemaul Undong is a great success in Korean history. However, in practice there do exist different national conditions and development stages between China and South Korea to some extent, so it is not rational to replicate Saemaul Undong in China. What we should do is to use the experience of Korea Saemaul Undong for reference and learn the guiding spirits of Korea Saemaul Undong (Diligence, Self-help and Cooperation).

\section{Acknowledgements}

The authors appreciate the anonymous reviewers' constructive comments and valuable suggestions, which have significantly improved the quality of this paper.

\section{References}

[1] Edward P. Reed. Is Saemaul Undong a Model for Developing Countries Today? September, 2010.

[2] Wang Jianhong. The Revaluation of South Korea's agricultural land reform. Jianghan Academic, 2015, Vol. 34 No. 4. (in Chinese).

[3] Saemaul Undong in Korea. Saemaul Training for Foreign Students in Korea Handouts. June, 2014.

[4] Copyright $@ 2014$ by Korea Saemaul Undong Center. Saemaul Undong in Korea.

[5] Wang Qiao. The Difference Comparison of Korea Saemaul Undong and China's New Countryside Construction. 2011. (in Chinese).

[6] Bin Wan, Yang Bai. THE INPUT-OUTPUT MODEL WITH RESOURCE CONSTRAINT EXTENSION. INTERNATIONAL JOURNAL OF ENGINEERING SCIENCES \& RESEARCH TECHNOLOGY. Vol. 6, No. 4, 2017, pp. 180-181.

[7] Yang Bai, Bin Wan, Yiyi Jiang, Jie Yan, Chonggao Liu. Pricing Model of Reverse Mortgage in China. Science Journal of Applied Mathematics and Statistics. Vol. 5, No. 2, 2017, pp. 94-97. doi: 10.11648/j.sjams.20170502.15.

[8] Ward SC, Chapman CB, Klein JH. Theoretical versus applied models: the newsboy problem. Omega 1991; 19: 197-206.

[9] Jaynes, E. T. 2003. Probability Theory: The Logic of Science. Cambridge University Press, Cambridge, UK.

[10] Suh-Ryung Kim, Jung Yeun Lee, Boram Park, and Yoshio Sano: The competition hypergraphs of doubly partial orders, Discrete Applied Mathematics, 165 (2014) 185-191. 